\title{
Studies of the toxicity of copper to pigs
}

\section{2.* Effect of protein source and other dietary components on the response to high and moderate intakes of copper}

\author{
By N. F. SUTTLE† AND C. F. MILLS \\ Rowett Research Institute, Bucksburn, Aberdeen \\ (Received 22 March 1965-Accepted I2 November 1965)
}

\begin{abstract}
1. Six groups of three (Expt 1 ) or four (Expt 2) female litter-mate Large White pigs were allocated after weaning to three or four treatments in a randomized block design. 2. In Expt 1,600 ppm copper were added to diets based on maize meal and containing either soya-bean meal, dried skim milk or white-fish meal to provide $16 \%$ total crude protein. Severity of Cu toxicosis was assessed by estimating aspartate transaminase (AST) activity in serum, Cu levels in serum and liver, haemoglobin concentration and the incidence of jaundice. 3. Toxicosis was severe only in pigs receiving white-fish meal, but liver $\mathrm{Cu}$ and haemoglobin levels were similar in all groups. 4. In Expt 2, 0, 250 or $425 \mathrm{ppm} \mathrm{Cu}$ or $425 \mathrm{ppm} \mathrm{Cu}+{ }_{50} \mathrm{ppm}$ zinc $+150 \mathrm{ppm}$ iron were added to the maize-white-fish meal diet from which the normal $\mathrm{Zn}$ and Fe supplements were omitted, creating optimal conditions for development of $\mathrm{Cu}$ toxicosis. 5 . In the absence of $\mathrm{Zn}$ and $\mathrm{Fe}$ supplements, $425 \mathrm{ppm} \mathrm{Cu}$ caused the development of a severe toxicosis. Simultaneous addition of $\mathrm{Zn}$ and $\mathrm{Fe}$ supplements eliminated all signs of toxicosis. 6. Under the same conditions $25^{\circ} \mathrm{ppm}$ Cu caused a mild toxicosis and also exaggerated the slight signs of parakeratosis or $\mathrm{Zn}$ deficiency noted in control animals. 7 . High calcium levels of $\mathbf{I} 7 \%$ in a basal diet containing $30 \mathrm{ppm} \mathrm{Zn}$ probably induced a marginal $\mathrm{Zn}$ deficiency which favoured the development of $\mathrm{Cu}$ toxicosis. Differences in calcium level were probably responsible for the apparent effects of the different protein supplements in Expt I. 8. Occasional occurrences of toxicity in pigs given $250 \mathrm{ppm} \mathrm{Cu}$ as a growth stimulant may be partly due to the use of diets low in $\mathrm{Zn}$ and $\mathrm{Fe}$ and high in calcium. Correcting these factors would extend the safety of $\mathrm{Cu}$ supplementation of the commercial diets.
\end{abstract}

There is evidence to suggest that the absorption or metabolism of trace elements is affected by the nature of the dietary protein. Thus the availability of zinc is increased when casein replaces soya-bean protein in the diet of rats (Forbes \& Yohe, I960), poultry (O'Dell \& Savage, I960) and pigs (Smith, Plumlee \& Beeson, I962). Davis, Norris \& Kratzer ( 1962 ) have found that the availability of copper and manganese is also low in diets containing soya-bean protein; the availability of molybdenum is similarly affected (Leach, Turk, Zeigler \& Norris, 1962). McCall, Mason \& Davis (196I) have shown that the toxicity of $\mathrm{Zn}$ to rats is less when soya-bean protein, rather than casein, is given. Many of these effects now appear to be related to the formation of metal-phytate complexes from interactions with phytic acid present in soya-bean meal (O'Dell \& Savage, I960; Oberleas, Muhrer \& O’Dell, I962). Sulphur-containing amino acids may also affect the toxicity of metals. Supplements of methionine have been shown to reduce the toxicity of cobalt to calves (Dunn, Ely \& Huffman, 1952) and Mo to rats (Gray \& Daniel, I954).

It appears from this evidence that protein sources differing in amino acid composition and in their ability to render minerals unavailable might also influence the toxicity

* Paper no. r; Br. F. Nutr. (1966), 20, I35.

$\dagger$ Present address: Moredun Institute, Edinburgh. 
of $\mathrm{Cu}$ to the pig. Expt I was designed to examine this hypothesis, with white-fish meal, soya-bean meal or dried skim milk as the sole protein supplement in diets supplemented with $600 \mathrm{ppm} \mathrm{Cu}$. Severe toxicity occurred only with white-fish meal in the diet.

Results from earlier experiments (Suttle \& Mills, I966) and from Expt I described in this communication suggested that $\mathrm{Cu}$ poisoning would be most likely to occur on diets free from supplementary $\mathrm{Fe}$ and $\mathrm{Zn}$ and containing white-fish meal as the protein supplement. The toxicity of $\mathrm{Cu}$ at or near the level recommended for practical use as a growth stimulant (cf. Braude, Townsend, Harrington \& Rowell, 1962; Lucas, Livingstone \& McDonald, I96I) was examined under these dietary conditions in Expt 2. Severe and mild toxicoses were produced by supplements providing 425 and $250 \mathrm{ppm}$ $\mathrm{Cu}$ respectively, and protection was achieved by adding $\mathrm{Zn}$ and $\mathrm{Fe}$.

\section{EXPERIMENTAL}

Animals. In both experiments, six groups of female litter-mate weanling Large White pigs, weighing about $17 \mathrm{~kg}$, were allocated according to live weight to a randomized block design with the litter as the experimental block. Litter groups of three and four pigs were used in Expts I and 2, respectively. Female pigs were used since other studies (Suttle, 1964) had shown that they were slightly more susceptible to $\mathrm{Cu}$ toxicosis than males.

Table I. Composition of diets used in Expt I

\begin{tabular}{|c|c|c|c|}
\hline & & Group & \\
\hline Component $(\%)$ & $\begin{array}{c}\text { Soya-bean } \\
\text { meal } \\
(\mathrm{SBM})\end{array}$ & $\begin{array}{c}\text { Dried skim } \\
\text { milk } \\
\text { (DSM) }\end{array}$ & $\begin{array}{c}\text { White-fish } \\
\text { meal } \\
\text { (WFM) }\end{array}$ \\
\hline Maize meal & 72 & 63 & 79 \\
\hline Soya-bean meal & 20 & - & - \\
\hline White-fish meal & 一 & - & $\mathbf{I 3}$ \\
\hline Dried skim milk & 一 & 29 & - \\
\hline Grass-meal & 5 & 5 & 5 \\
\hline Ground limestone & I & I & $\mathbf{I}$ \\
\hline Sterilized bone meal & I & I & $\mathbf{I}$ \\
\hline Vitamin supplement* & 0.5 & 0.5 & 0.5 \\
\hline Mineral supplement $†$ & 0.5 & 0.5 & 0.5 \\
\hline Mineral content (ppm & Ary food): & & \\
\hline $\mathrm{Cu}$ & 640 & 623 & 649 \\
\hline $\mathrm{Zn}$ & 42 & 40 & $4 I$ \\
\hline $\mathrm{Fe}$ & 120 & 90 & I 38 \\
\hline
\end{tabular}

* Provided $132 \mathrm{mg}$ vitamin A, I $\mathrm{mg}$ ergocalciferol, $880 \mathrm{mg}$ DL- $\alpha$-tocopheryl acetate, $0.55 \mathrm{mg}$ cyanocobalamin, $198 \mathrm{mg}$ riboflavine, $\mathrm{I} .45 \mathrm{~g}$ pyridoxine, $0.66 \mathrm{~g}$ calcium pantothenate, $88 \mathrm{~g}$ choline chloride, $2 \cdot 2 \mathrm{~g}$ nicotinic acid, $0 \cdot 22 \mathrm{~g}$ thiamine, $O \cdot \mathrm{I}_{\mathrm{I}} \mathrm{g}$ folic acid.

$\dagger$ Provided $466 \mathrm{~g} \mathrm{NaCl}, 18.9 \mathrm{~g} \mathrm{MnSO}_{4} . \mathrm{H}_{2} \mathrm{O}$, $13.4 \mathrm{~g} \mathrm{FeSO} .7 \mathrm{H}_{2} \mathrm{O}, 0.207 \mathrm{~g} \mathrm{CoCO}, 5.78 \mathrm{~g} \mathrm{ZnSO}_{4}$. ${ }_{7} \mathrm{H}_{2} \mathrm{O}$.

Treatments. The basal diet in Expt I was similar to that previously described (Suttle \& Mills, I966). White-fish meal (WFM) or dried skim milk (DSM) replaced soya-bean meal (SBM) as the protein supplement in diets containing $600 \mathrm{ppm}$ supplementary $\mathrm{Cu}\left(\right.$ as $\left.\mathrm{CuCO}_{3} \cdot \mathrm{Cu}(\mathrm{OH})_{2} \cdot \mathrm{H}_{2} \mathrm{O}\right)$. The proportion of maize meal in the 
diet was adjusted to compensate for the inclusion of materials differing in protein concentration in diets that provided $16 \%$ crude protein and $73-77 \%$ total digestible nutrients. The compositions of the three experimental diets are given in Table $\mathrm{I}$.

The basal diet for Expt 2 was similar to the diet containing WFM in Expt I except that the supplements of $\mathrm{Cu}(600 \mathrm{ppm}), \mathrm{Zn}$ (13 ppm) and $\mathrm{Fe}$ (3० ppm) were omitted. Different batches of foodstuffs were used in the two experiments. Basal diet 2 contained $5 \mathrm{ppm} \mathrm{Cu}, 30 \mathrm{ppm} \mathrm{Zn}$ and $\mathrm{I} 68 \mathrm{ppm} \mathrm{Fe}$. The four treatment groups received either o, 250, $425 \mathrm{ppm} \mathrm{Cu}\left(\right.$ as $\mathrm{CuSO}_{4} \cdot 5_{2} \mathrm{H}_{2} \mathrm{O}$ ) or $425 \mathrm{ppm} \mathrm{Cu}+{ }_{15}^{\circ} \mathrm{ppm} \mathrm{Zn}$ (as $\mathrm{ZnSO}_{4} \cdot 7 \mathrm{H}_{2} \mathrm{O}$ ) $+15 \circ \mathrm{ppm} \mathrm{Fe}$ (as $\mathrm{FeSO}_{4} \cdot{ }_{7} \mathrm{H}_{2} \mathrm{O}$ ) as supplements to the basal diet. In previous experiments (Suttle \& Mills, 1966) and in Expt $\mathrm{I}$ of this series, $\mathrm{Cu}$ was added as basic $\mathrm{CuCO}_{3}$ to eliminate unpalatability at high $\mathrm{Cu}$ levels. The sulphate was used to provide the lower $\mathrm{Cu}$ levels in the final experiment, since this salt is used commercially as a feed additive.

Management, collection of samples and analytical methods. Expts $\mathrm{I}$ and 2 were terminated after 48 and 79 days respectively, when the pigs were slaughtered and samples of liver tissue taken. Samples of whole blood and serum were taken regularly during each experiment. Haemoglobin level, $\mathrm{Cu}$ and $\mathrm{Zn}$ in serum and liver and aspartate transaminase activity in serum were determined by the methods given in a previous paper (Suttle \& Mills, 1966); other details of management and collection of samples given in that paper apply also to the experiments to be described.

Statistical analysis. The significance of treatment differences was assessed by conventional analysis of variance procedures for randomized block designs. The number of replicates from which the means are derived is only given when it was less than the scheduled sixfold replication. Logarithmic transformations were used where necessary. Components of the growth curves in Expt 2 were obtained by the use of orthogonal polynomials.

\section{RESULTS}

\section{Expt I}

Live-weight gain, food consumption and food conversion efficiency. The growth curves for the treatment groups given in Fig. I show that there was a slight depression in the growth of group SBM after the 28th day, whereas a gradual acceleration of growth would normally be found. A simultaneous and more noticeable check in growth occurred in group DSM. Only one of the twelve animals from these two groups showed gross signs of $\mathrm{Cu}$ toxicosis, including jaundice. Four animals from group WFM showed a visible loss of condition and jaundice, and the mean growth rate was noticeably retarded after the 2Ist day. Analysis of the results for performance over a period of 42 days (Table 2) showed that both increase in weight and food conversion efficiency in group WFM were significantly inferior to those shown by group SBM, and food consumption also tended to be lower. Group DSM grew significantly faster than group WFM and more slowly than group SBM.

Serum $C u$ and aspartate transaminase $(A S T)$ concentrations. In all groups serum $\mathrm{Cu}$ levels followed a pattern (Fig. 2) similar to that shown by $\mathrm{Cu}$-supplemented animals in the preceding paper (Suttle \& Mills, 1966), rising rapidly in the early weeks of the 
experiment and declining later. The results for groups SBM and DSM were similar but their mean values were consistently lower than those for group WFM throughout the experiment. This difference was significant at the 26th day $(P<0.05)$, despite wide individual variation. Two animals from group WFM had serum $\mathrm{Cu}$ concentrations of 256 and $301 \mu \mathrm{g} / \mathrm{roO} \mathrm{ml}$ at that time. Values for the remaining four animals, in which jaundice was evident, were between 430 and $55^{\circ} \mu \mathrm{g} / \mathrm{roo} \mathrm{ml}$. Values for serum AST activity were generally highest in the WFM group and this evidence of tissue damage persisted until the close of the experiments, despite the fall in serum Cu levels

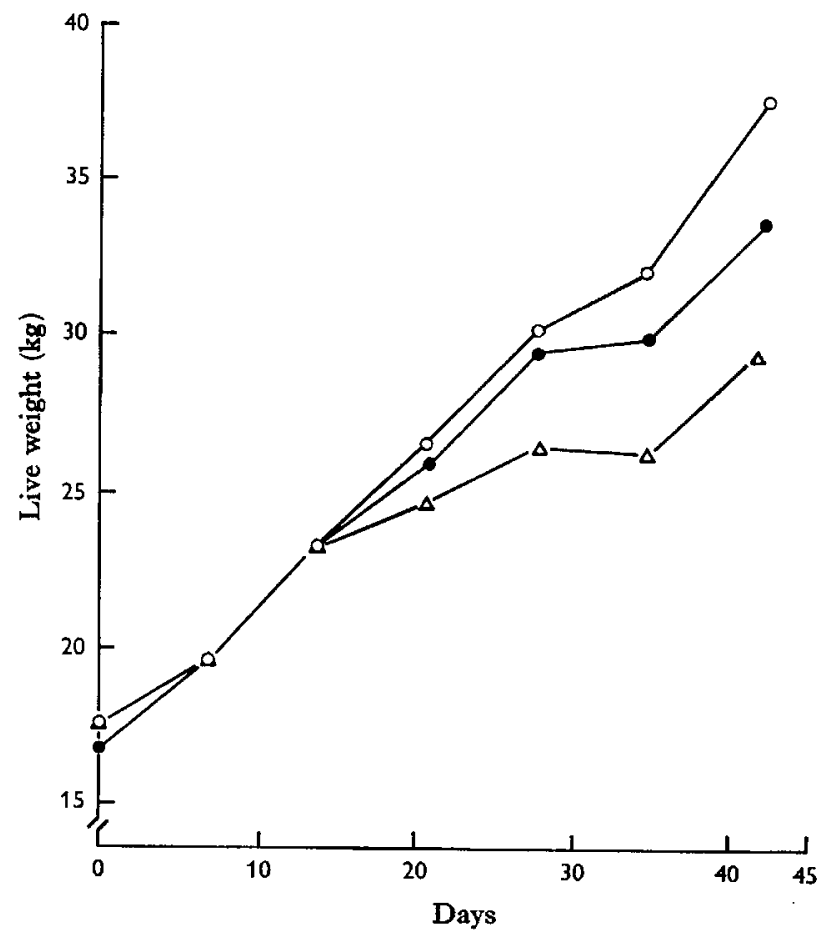

Fig. I, Expt I. Effect of three dietary protein supplements on the growth of pigs receiving a supplement of $600 \mathrm{ppm}$ copper. $0-0$, soya-bean meal; $\bullet-\bullet$, dried skim-milk powder; $\Delta-\Delta$, white-fish meal.

Table 2. Expt I. Effect of protein supplement on the performance of pigs given 600 ppm supplementary copper for $4^{2}$ days

\begin{tabular}{|c|c|c|c|c|}
\hline Protein supplement & $\begin{array}{c}\text { No. of } \\
\text { pigs }\end{array}$ & $\begin{array}{c}\text { Total } \\
\text { live-weight } \\
\text { gain } \\
(\mathrm{kg})\end{array}$ & $\begin{array}{l}\text { Total food } \\
\text { consumption } \\
(\mathrm{kg})\end{array}$ & $\begin{array}{c}\text { Food } \\
\text { conversion } \\
\text { efficiency }\end{array}$ \\
\hline $\begin{array}{l}\text { Soya-bean meal } \\
\text { Dried skim milk } \\
\text { White-fish meal } \\
\text { Residual sD } \\
\text { Overall significance }\end{array}$ & $\begin{array}{l}6 \\
6 \\
6\end{array}$ & $\begin{array}{c}20.6 \\
16.8 \\
11 \cdot 1 \\
\pm 1.3 \\
P<0.001\end{array}$ & $\begin{array}{c}63.2 \\
53.5 \\
47.3 \\
\pm 12.9 \\
0.05<P<0.1\end{array}$ & $\begin{aligned} & 3.10 \\
& 3.71 \\
& 5.03 \\
& \pm 1.08 \\
& P<0.05\end{aligned}$ \\
\hline
\end{tabular}

$\dagger$ Food consumed (kg)/live-weight gain $(\mathrm{kg})$. 
(Fig 3). Individual variation was again prominent; two animals from the group receiving diet WFM at no time showed elevated AST levels. The gradual elevation of AST activity in group SBM was due to increases in the one animal showing jaundice

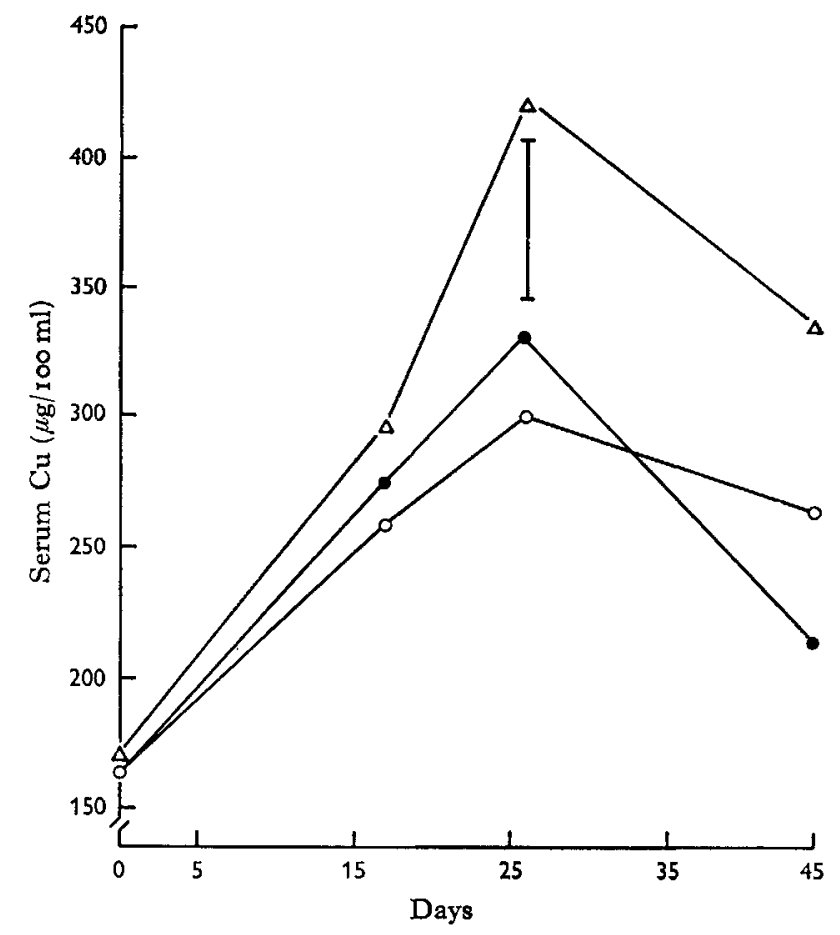

Fig. 2. Expt 1. Effect of three protein supplements on serum copper concentrations in pigs receiving a supplement of $600 \mathrm{ppm} \mathrm{Cu}$. $\circ-0$, soya-bean meal; $\bullet-\bullet$, dried skim-milk powder; $\Delta-\Delta$, white-fish meal. Vertical bar denotes least significant difference at the $5 \%$ level of probability.

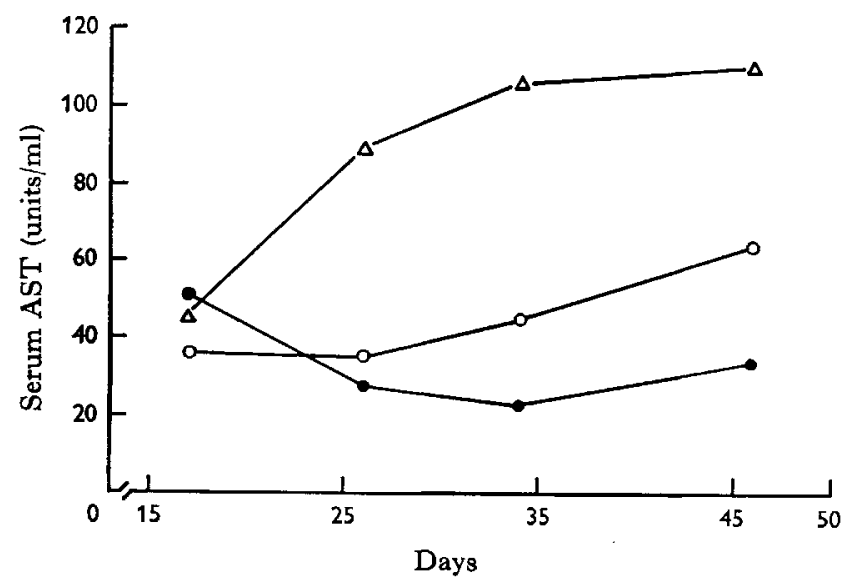

Fig. 3. Expt I. Effect of three protein supplements on aspartate transaminase activity in the serum of pigs receiving a supplement of 600 ppm copper, $०-0$, soya-bean meal; $\bullet-\bullet$, dried skim-milk powder; $\Delta-\Delta$, white-fish meal. 
and having an excessively high serum $\mathrm{Cu}$ concentration. Other animals from this group and from group DSM showed no signs of tissue damage or jaundice, and their serum $\mathrm{Cu}$ concentrations did not rise above $355 \mu \mathrm{g} /$ roo ml. Analysis of the logarithmic values for AST activity at the 26th day showed that the mean values were $\mathrm{I} \cdot 67, \mathrm{I} \cdot 50$ and $\mathrm{I} \cdot 94$ units $/ \mathrm{ml}$ serum for groups SBM, DSM and WFM, respectively and that the difference between the latter groups was significant $(P<0.05)$.

Haemoglobin level. Anaemia developed gradually in all groups and in all animals; mean serum haemoglobin values were I I 86 , I I 68 and I I $49 \mathrm{~g} / 100 \mathrm{ml}$ at the beginning and $8.75,7.34$ and $7.02 \mathrm{~g} / 100 \mathrm{ml}$ at the end of the experiment in groups SBM, DSM and WFM, respectively. The standard error of the difference between mean falls in haemoglobin level was \pm 0.98 , and there were no significant differences between the treatment groups.

Table 3. Expt I. Effect of protein supplement on the accumulation of copper in the liver of pigs given $600 \mathrm{ppm}$ supplementary Cu for 48 days

\begin{tabular}{|c|c|c|c|}
\hline Protein supplement & $\begin{array}{c}\text { Liver } \mathrm{Cu} \\
\text { concentration } \\
\text { (ppm DM) }\end{array}$ & $\begin{array}{l}\text { Total liver Cu } \\
\text { (mg) }\end{array}$ & $\begin{array}{c}\text { Retention of } \\
\text { ingested Cu } \\
\text { in the liver* } \\
(\%)\end{array}$ \\
\hline $\begin{array}{l}\text { Soya-bean meal } \\
\text { Dried skim milk } \\
\text { White-fish meal } \\
\text { Residual sD } \\
\text { Overall significance }\end{array}$ & $\begin{array}{r}2373 \\
2146 \\
2479 \\
\pm 623 \\
\text { NS }\end{array}$ & $\begin{array}{c}630 \\
530 \\
480 \\
\pm 81 \\
P<0.05\end{array}$ & $\begin{array}{r}I \cdot 26 \\
I \cdot 28 \\
I \cdot 3 I \\
\pm 0 \cdot 2 I \\
N S\end{array}$ \\
\hline
\end{tabular}

Accumulation of $\mathrm{Cu}$ in the liver. The results given in Table 3 show that there were no significant treatment differences in liver $\mathrm{Cu}$ concentrations or in the retentions of ingested $\mathrm{Cu}$ in the liver. The values for liver $\mathrm{Cu}$ retention were obtained by expressing total liver $\mathrm{Cu}$ content at slaughter as a percentage of the $\mathrm{Cu}$ ingested. This ignores the small contribution of about $8 \mathrm{mg} \mathrm{Cu}$ that would normally be found in livers of pigs of similar live weight given unsupplemented diets. The differences in total liver $\mathrm{Cu}$ content were solely due to differences in total liver weight in animals of different body-weight.

\section{Expt 2}

Live-weight gain, food consumption and food conversion efficiency. The addition of $25^{\circ}$ and $42.5 \mathrm{ppm} \mathrm{Cu}$ to a maize-fish-meal diet produced diverging growth curves, which were altered further by including a supplement of $\mathrm{Fe}$ and $\mathrm{Zn}$ with the higher addition of $\mathrm{Cu}$. The relationship of the resultant growth curves to that of unsupplemented control animals is shown in Fig. 4. A supplement providing $25^{\circ} \mathrm{ppm} \mathrm{Cu}$ produced a growth response over the first 30 days of treatment, but this effect had disappeared by the $77_{\text {th }}$ day. Increasing the $\mathrm{Cu}$ level to $425 \mathrm{ppm}$ caused a severe growth depression after 14 days, when severe toxicosis became evident; three pigs were slaughtered on the $47^{\text {th }}$ day and a further one on the 6oth day to prevent unnecessary suffering. Autopsy revealed generalized jaundice, hypertrophy and 
cirrhosis of the liver and gastro-intestinal haemorrhage. In contrast, the group receiving $150 \mathrm{ppm}$ supplementary $\mathrm{Fe}$ and $\mathrm{Zn}$ in addition to $425 \mathrm{ppm} \mathrm{Cu}$ had a significantly better growth rate, food consumption and food conversion efficiency than the unsupplemented group. Further findings on the performance of the three surviving

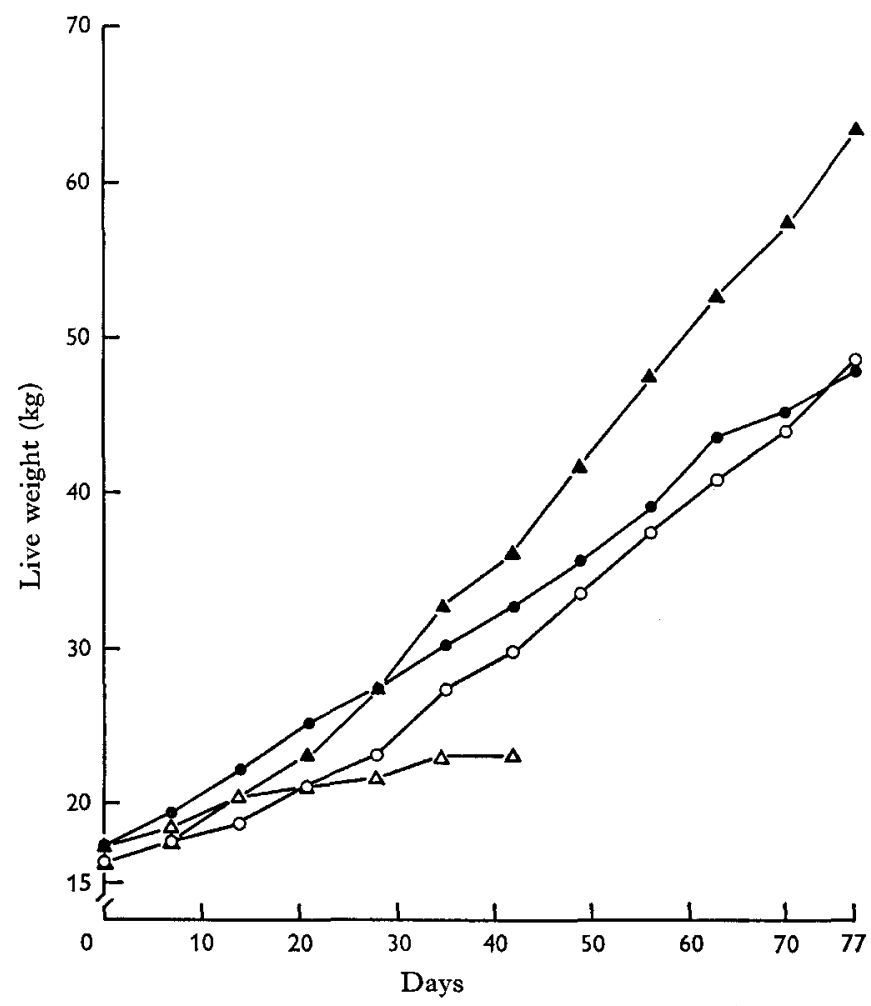

Fig. 4. Expt 2. Effect of mineral supplements in a maize-white-fish meal diet on growth rate of pigs. $\curvearrowright-\circ$, no supplement; $-250 \mathrm{ppm}$ copper; $\Delta-\Delta 425 \mathrm{ppm}$ copper; $\Delta-425 \mathrm{ppm}$ copper +150 ppm zinc +150 ppm iron.

Table 4. Expt 2. Effect of supplementary copper in the presence or absence of added iron and zinc on weight gain, food consumption and food conversion efficiency in pigs over a period of 79 days

\begin{tabular}{|c|c|c|c|c|}
\hline \multirow{2}{*}{$\begin{array}{l}\text { Dietary supplement } \\
\text { (ppm air-dry food) }\end{array}$} & \multicolumn{2}{|c|}{$\begin{array}{l}\text { Components of } \\
\text { growth curve } \\
\text { (kg/week) }\end{array}$} & \multirow{2}{*}{$\begin{array}{l}\text { Total food } \\
\text { consumption } \\
(\mathrm{kg})\end{array}$} & \multirow{2}{*}{$\begin{array}{l}\text { Food conversion } \\
\text { efficiency* }\end{array}$} \\
\hline & Linear & Quadratic & & \\
\hline None & $3^{\circ} \cdot 3$ & 0.046 & $109^{-1}$ & $3 \cdot 43$ \\
\hline $25^{\circ} \mathrm{Cu} \uparrow$ & $3 \cdot 22$ & 0.024 & $112 \cdot 6$ & $3 \cdot 29$ \\
\hline $\begin{array}{l}425 \mathrm{Cu}+150 \mathrm{Fe} \\
+\mathrm{I} 50 \mathrm{Zn}\end{array}$ & 4.55 & $0.06 \mathrm{I}$ & $139^{\circ} \mathrm{I}$ & $2 \cdot 93$ \\
\hline $\begin{array}{l}\text { Residual SD } \\
\text { Overall significance }\end{array}$ & $\begin{array}{c} \pm 0.74 \\
P<0.05\end{array}$ & $\begin{array}{l} \pm 0.019 \\
P<0.05\end{array}$ & $\begin{array}{c} \pm 23.4 \\
0.1>P>0.05\end{array}$ & $\begin{array}{l} \pm 0.30 \\
P<0.05\end{array}$ \\
\hline
\end{tabular}

* Food consumed (kg)/live-weight gain (kg).

$\dagger$ Includes one 'missing plot value' for an animal showing extremely poor growth. 
groups are given in Table 4. The overall performances of the unsupplemented and $25^{\circ} \mathrm{ppm}$ Cu groups were similar, but the acceleration of growth in the Cu-supplemented group, as measured by the quadratic component of the growth curve, was almost significantly slower $(0.05<P<0.1)$.

Table 5. Expt 2. Effect of supplementary copper, in the presence or absence of supplementary iron and zinc, on the extent of keratinous lesions on the rear legs of pigs

\begin{tabular}{|c|c|c|c|c|}
\hline \multirow{2}{*}{$\begin{array}{l}\text { Dietary supplement } \\
\text { (ppm air-dry food) }\end{array}$} & \multicolumn{4}{|c|}{ Day of experiment } \\
\hline & 30 & 47 & 60 & 77 \\
\hline None & $\circ$ & 0.3 & 0.2 & 0.7 \\
\hline $250 \mathrm{Cu}$ & 0.5 & $\mathrm{I} \cdot 8$ & $I \cdot 3$ & I.7 \\
\hline $425 \mathrm{Cu}$ & o & 0 & of & of \\
\hline $425 \mathrm{Cu}+1_{5} \circ \mathrm{Fe}+1_{50} \mathrm{Zn}$ & $\mathbf{0}$ & 0.5 & 0.2 & 0 \\
\hline
\end{tabular}

* Values represent the mean of six individual scores, using a scale in which $0=$ no, $I=$ slight, $2=$ moderate and $3=$ severe lesions.

+ Results from two surviving pigs only.

The relatively poor performance of the groups receiving no supplement or $25^{\circ} \mathrm{ppm}$ $\mathrm{Cu}$ was apparently associated with the development of skin lesions similar to those described in parakeratosis (Kernkamp \& Ferrin, 1953). The development of these lesions during the experiment is illustrated by the results in Table 5 . Lesions on the rear legs were classified as slight (appearance of pimple-like outgrowths), moderate (enlargement of outgrowths to about $\mathrm{I} \mathrm{cm}$ diameter and their extension in numbers to cover the thighs and hocks) or severe (eruption and coalescence of lesions to form large keratinized areas). Lesions were first noticed after 30 days in three animals from the group receiving $25^{\circ} \mathrm{ppm} \mathrm{Cu}$. By the $47^{\text {th }}$ day these lesions had become generally moderate in severity and in some pigs extended to the back and belly. This condition persisted throughout the experiment, and one animal that became severely affected had to be slaughtered. The unsupplemented group and the group given $425 \mathrm{ppm} \mathrm{Cu}+$ $\mathrm{Fe}+\mathrm{Zn}$ had also become slightly affected by the $47^{\text {th }}$ day. The skin lesions were completely absent from the latter group at the close of the experiment, but increased in severity in the control group, although never reaching the severity shown by the group receiving $25^{\circ} \mathrm{ppm} \mathrm{Cu}$. The two surviving pigs in the group receiving $425 \mathrm{ppm}$ $\mathrm{Cu}$ developed lesions on the back as the experiment progressed.

Serum $Z n$ concentrations. Some difficulty was found in determining the small quantities of $\mathrm{Zn}$ in individual serum samples. At the $45^{\text {th }}$ day pooled samples from the treatment groups contained 39,28 and $37 \mu \mathrm{g} \mathrm{Zn} / 100 \mathrm{ml}$ in the control group and the groups receiving $25^{\circ} \mathrm{ppm} \mathrm{Cu}$ and $425 \mathrm{ppm} \mathrm{Cu}$ respectively. The addition of $\mathrm{Zn}$ and $\mathrm{Fe}$ to the diet increased the concentration to $70 \mu \mathrm{g} / \mathrm{I00} \mathrm{ml}$. These results can be compared with the value of $56 \mu \mathrm{g} / \mathrm{roo} \mathrm{ml}$ found in healthy control pigs by Hoekstra, Lewis, Phillips \& Grummer (1956).

Haemoglobin level. Haemoglobin levels remained normal throughout except in animals from the group receiving $425 \mathrm{ppm} \mathrm{Cu}$ that were slaughtered after $\mathrm{Cu}$ toxicosis had developed. The marked anaemia then observed was probably associated with the gastro-intestinal haemorrhage found at autopsy. 
Serum $\mathrm{Cu}$ and AST concentrations and incidence of jaundice. Figs. 5 and 6 show that the external manifestations of toxicosis in the group receiving $425 \mathrm{ppm} \mathrm{Cu}$ were accompanied by marked increases in the $\mathrm{Cu}$ and AST concentrations in the serum, and jaundice was observed in each member of the group. Signs of toxicosis were less evident in the group receiving $25^{\circ} \mathrm{ppm} \mathrm{Cu}$, but both AST and $\mathrm{Cu}$ concentrations in serum were significantly greater than control values at the 46 th day, when three

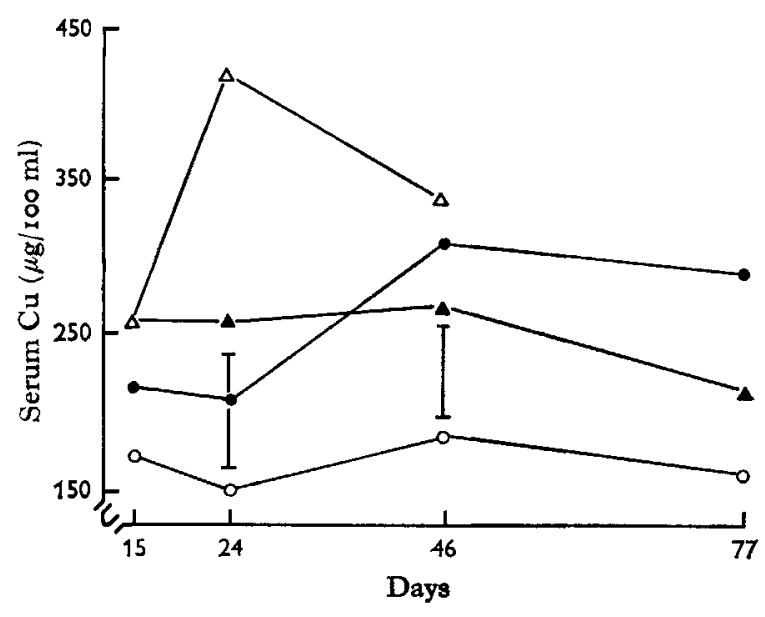

Fig. 5

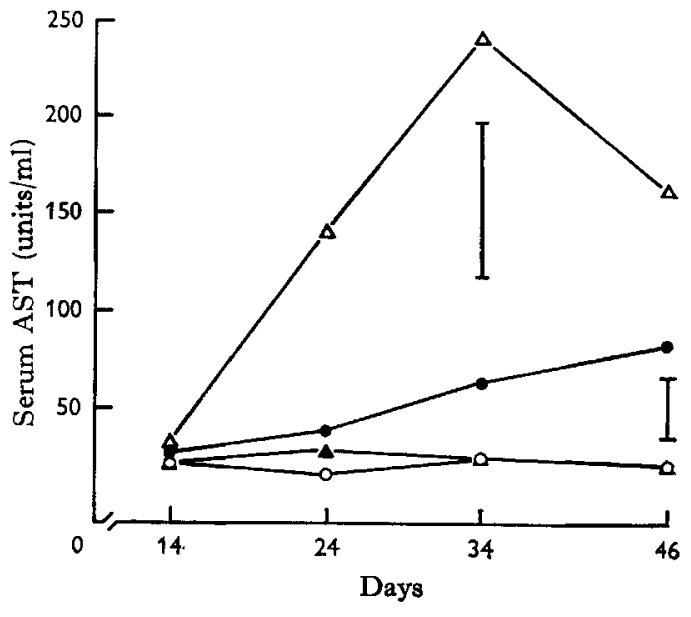

Fig. 6

Fig. 5. Expt 2. Effect of mineral supplements in a maize-white-fish meal diet on serum copper concentration in the pig. $\bigcirc-\circ$, no supplement; $-\bullet, 250 \mathrm{ppm} \mathrm{Cu} ; \Delta-\Delta, 425 \mathrm{ppm} \mathrm{Cu} ; \Delta-\Delta$, $425 \mathrm{ppm} \mathrm{Cu}+$ I $_{50} \mathrm{ppm} \mathrm{Zn}+$ I $_{5}$ o ppm Fe. Vertical bars denote least significant difference at the $5 \%$ level of probability.

Fig. 6. Expt 2. Effect of mineral supplements in a maize-white-fish meal diet on aspartate transaminase in the serum of the pig. $\circ-0$, no supplement; $-\bullet, 250 \mathrm{ppm} \mathrm{Cu;} \Delta-\Delta$, $425 \mathrm{ppm} \mathrm{Cu} ;-\wedge, 425 \mathrm{ppm} \mathrm{Cu}+150 \mathrm{ppm} \mathrm{Zn}+150 \mathrm{ppm} \mathrm{Fe}$. Vertical bars denote least significant difference at the $5 \%$ level of probability.

Table 6. Expt 2. Effect of supplementary copper, in the presence or absence of added iron and zinc, on the accumulation of $\mathrm{Zn}$ and $\mathrm{Cu}$ in the liver of pigs after 79 days

\begin{tabular}{|c|c|c|c|c|c|c|}
\hline \multirow[b]{2}{*}{$\begin{array}{l}\text { Dietary supplement } \\
\text { (ppm air-dry food) }\end{array}$} & \multicolumn{2}{|c|}{$\begin{array}{c}\text { Liver Cu } \\
\text { concentration } \\
\text { (ppm DM) }\end{array}$} & \multicolumn{2}{|c|}{$\begin{array}{l}\text { Total liver } \\
\text { Cu content } \\
\text { (mg) }\end{array}$} & \multirow{2}{*}{$\begin{array}{c}\text { Retention } \\
\text { of sup- } \\
\text { plementary } \\
\text { Cu in liver* } \\
(\%)\end{array}$} & \multirow{2}{*}{$\begin{array}{c}\text { Liver } \\
\text { Zn con- } \\
\text { centration } \\
\text { (ppm DM) }\end{array}$} \\
\hline & $\underset{\text { mean }}{\text { Log }}$ & $\begin{array}{c}\text { Derived } \\
\text { mean }\end{array}$ & $\underset{\text { mean }}{\log }$ & $\begin{array}{l}\text { Derived } \\
\text { mean }\end{array}$ & & \\
\hline Sone & $\mathbf{I} \cdot 78$ & 62 & 1.25 & 19 & - & 106 \\
\hline 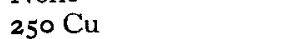 & $3 \cdot 3$ & 208 & 2. & 45 & $I \cdot 53$ & 163 \\
\hline${ }_{5} \mathrm{Cu} \dagger$ & 3. & 2770 & 2.60 & 424 & $\begin{array}{l}1.69 \\
\end{array}$ & 153 \\
\hline $\begin{array}{l}425 \mathrm{Cu} \dagger+150 \mathrm{Fe} \\
+150 \mathrm{Zn}\end{array}$ & 3.35 & 2280 & 2.92 & 875 & $1 \cdot 27$ & 277 \\
\hline $\begin{array}{l}\text { Residual SD } \\
\text { Overall significance }\end{array}$ & $\begin{array}{l} \pm 0.01 \\
P<0.001\end{array}$ & - & $P \stackrel{ \pm 0.15}{<0.001}$ & - & $\begin{array}{l} \pm 0.17 \\
P<0.01\end{array}$ & $P \stackrel{ \pm 72}{<0.05}$ \\
\hline
\end{tabular}

DM, dry matter.

* Total liver $\mathrm{Cu}(\mathrm{mg}) /$ ingested $\mathrm{Cu}(\mathrm{mg}) \times$ roo.

$\uparrow$ Includes values for four pigs that were slaughtered prematurely.

f Includes one 'missing plot value' for a liver containing only $78_{5} \mathrm{ppm} \mathrm{Cu}$. 
animals showed signs of jaundice. In the presence of additional $\mathrm{Zn}$ and $\mathrm{Fe}$, the supplement of $425 \mathrm{ppm} \mathrm{Cu}$ caused serum Cu levels to rise initially to $260 \mu \mathrm{g} / 100 \mathrm{ml}$, but there was little further increase; the concentrations did not apparently become great enough to produce any increase in serum AST levels or any sign of jaundice.

Accumulation of $Z n$ and $C u$ in liver tissue. There was a considerable accumulation of $\mathrm{Cu}$ in the livers of all pigs receiving supplementary $\mathrm{Cu}$, the increase being significantly $(P<0.05)$ greater with $425 \mathrm{ppm} \mathrm{Cu}$ than in the other supplemented groups (Table 6). The retention of supplementary $\mathrm{Cu}$ in the liver was significantly reduced by adding $15^{\circ} \mathrm{ppm} \mathrm{Fe}$ and $15^{\circ} \mathrm{ppm} \mathrm{Zn}$ to the diet containing $425 \mathrm{ppm}$ supplementary $\mathrm{Cu}$. The value of assessing retention of $\mathrm{Cu}$ in liver in this way is demonstrated here, since effects of treatment on accumulation of $\mathrm{Cu}$ in the liver are not apparent from the values for liver $\mathrm{Cu}$ concentration and total liver $\mathrm{Cu}$ content. The increase in liver $\mathrm{Cu}$ concentration was accompanied by an increase in liver $\mathrm{Zn}$, as in previous experiments (Suttle \& Mills, 1966). $\mathrm{Zn}$ accumulation was greatest in the group receiving supplementary $\mathrm{Fe}, \mathrm{Zn}$ and $\mathrm{Cu}$.

\section{DISCUSSION}

The addition of $600 \mathrm{ppm} \mathrm{Cu}$ to the maize-soya-bean meal diet in Expt I produced a slight growth depression and temporary increase in the serum $\mathrm{Cu}$ level, but obvious toxicosis was only noticed in one of the six pigs so treated. This amount probably represented the marginally toxic $\mathrm{Cu}$ concentration under these experimental conditions, in which $\mathrm{Fe}$ and $\mathrm{Zn}$ supplements were included in the diet. A more severe toxicosis was produced in earlier experiments (Suttle \& Mills, I966) when $750 \mathrm{ppm}$ $\mathrm{Cu}$ were added to a similar diet. Again, using a similar diet in Florida, Wallace, $\mathrm{McCall}$, Bass \& Combs ( 1960 ) found that a Cu concentration as low as $25^{\circ} \mathrm{ppm}$ could cause toxicity. This suggests that factors other than those of a simple nutritional origin may contribute to the development of $\mathrm{Cu}$ toxicosis.

In our study the replacement of soya-bean meal with dried skim milk in diets supplemented with $600 \mathrm{ppm} \mathrm{Cu}$ was accompanied by a slight growth depression, but liver and serum $\mathrm{Cu}$ and serum AST concentrations were largely unaffected by the change. The higher content of phytic acid in the soya-bean meal diet did not exert its expected effect of reducing the availability and the toxicity of $\mathrm{Cu}$. The introduction of white-fish meal to the diet caused a fairly severe toxicosis to develop in four out of six pigs given the supplement providing $600 \mathrm{ppm} \mathrm{Cu}$. Serum $\mathrm{Cu}$ and AST levels rose two to five times above their initial concentration and jaundice developed. The small differences in the $\mathrm{Cu}$ content of the diets before $\mathrm{Cu}$ supplementation, evident from Table I, were not considered sufficient to have influenced the course of the experiment.

There are several differences in composition between the diets containing whitefish meal, on the one hand, and dried skim milk or soya-bean meal, on the other. The diet with white-fish meal was lower in tryptophan and phenylalanine than the other diets, but there is no suggestion that such differences would influence $\mathrm{Cu}$ metabolism. The most obvious difference between the three protein sources is in their mineral content and particularly in the amounts of calcium and phosphorus that they contribute. The Ca and P contents of diets SBM, DSM and WFM were calculated to be 
$0.8 \mathrm{I}$ and $0.53, \mathrm{I} \cdot \mathrm{I}_{5}$ and 0.56 , and $\mathrm{I} .68$ and $0.87 \%$ respectively. High Ca levels have been found to exaggerate or induce signs of $\mathrm{Zn}$ deficiency in pigs receiving diets based on maize and soya-bean meal (Tucker \& Salmon, 1955; Stevenson \& Earle, 1956; Lewis, Hoekstra \& Grummer, 1957) and in animals receiving a cereal mixture with fish meal providing some of the protein (Bellis \& Philp, I957; Hansen \& Dishington, I960). The appearance in Expt 2 of slight parakeratotic lesions in animals receiving the unsupplemented diet containing only $3 \circ \mathrm{ppm} \mathrm{Zn}$ and $\mathrm{I} \cdot 7 \% \mathrm{Ca}$ is in accordance with these findings. The serum $\mathrm{Zn}$ concentration was low and liver $\mathrm{Zn}$ concentrations were about 6o ppm lower than those found in control pigs in earlier experiments (Suttle \& Mills, ı g66).

A complex interrelationship exists between the incidence of $\mathrm{Zn}$ deficiency and the response to $\mathrm{Cu}$ supplements. Ritchie, Luecke, Baltzer, Miller, Ullrey \& Hoefer (I963) found that $250 \mathrm{ppm} \mathrm{Cu}$ were toxic to pigs when added to a diet that, when unsupplemented, produced parakeratosis. They used a maize-soya-bean diet containing $\mathrm{I} \cdot 3 \%$ calcium. In earlier work with a diet containing $0.65 \% \mathrm{Ca}$, parakeratosis was not observed and the same $\mathrm{Cu}$ level did not produce toxicity (Ritchie, Luecke, Baltzer, Miller, Ullrey \& Hoefer, 1962). Wallace et al. (I960) did not find such an association in separate experiments in which $250 \mathrm{ppm} \mathrm{Cu}$ produced toxicosis in the absence of parakeratosis, whereas $300 \mathrm{ppm} \mathrm{Cu}$ failed to produce toxicosis in the presence of parakeratosis in control animals. These results suggest that the presence of $\mathrm{Zn}$ deficiency may not therefore be necessary for the development of $\mathrm{Cu}$ toxicosis at relatively low dietary $\mathrm{Cu}$ levels. Both groups of workers confirmed the earlier observation of Hoefer, Miller, Ullrey, Ritchie \& Luecke (I960) that supplementary Cu afforded protection against the development of parakeratosis. However, in our studies and also in those of O'Hara, Newman \& Jackson (I960), the addition of $25^{\circ} \mathrm{ppm} \mathrm{Cu}$ exacerbated or induced a state of $\mathrm{Zn}$ deficiency and simultaneously produced $\mathrm{Cu}$ toxicosis.

A further anomaly existed in the failure of a $425 \mathrm{ppm} \mathrm{Cu}$ supplement in Expt 2 to exacerbate the $\mathrm{Zn}$ deficiency. The incidence of parakeratosis has been found to be high under conditions of ad lib. feeding and rapid growth (Lewis, Grummer \& Hoekstra, 1956) and in pigs of between 10 and 16 weeks of age (Stevenson \& Earle, I956). Månsson, Askling \& Manheim (1964) observed that serum Zn concentrations in healthy pigs tended to be lowest at about 14 weeks of age. It is possible that the indefinite relationship between the incidence of parakeratosis and $\mathrm{Cu}$ toxicosis during $\mathrm{Cu}$ supplementation may have resulted from the use of pigs varying in susceptibility to parakeratosis, owing to differences in age and growth rate. Thus the stunted growth in the $425 \mathrm{ppm} \mathrm{Cu}$ group in Expt 2 might have reduced the development of parakeratosis. Variations between experimental locations in dietary $\mathrm{Cu}$ and $\mathrm{Zn}$ concentrations and in the access to adventitious sources of $\mathrm{Zn}$, such as galvanized feeding troughs, might also have contributed to the contradictory results reported by different workers.

In our investigations, a supplement of $425 \mathrm{ppm} \mathrm{Cu}$ was more toxic, in conditions favouring the development of $\mathrm{Zn}$ deficiency, than $75^{\circ} \mathrm{ppm} \mathrm{Cu}$ in an earlier experiment in which $\mathrm{Zn}$ deficiency was not apparent. In that experiment the addition of $\mathrm{Zn}$ reduced the severity of $\mathrm{Cu}$ toxicosis (Suttle \& Mills, 1966). It is probable that the occurrence of parakeratosis in Expt 2 was chiefly due to the use of a basal diet contain- 
ing the high level of about $\mathrm{I} \cdot 7 \% \mathrm{Ca}$. It thus becomes evident that the equally high $\mathrm{Ca}$ content of the diet containing white-fish meal in Expt I may also have adversely influenced $\mathrm{Zn}$ availability. In turn this may have been responsible for the appearance of severe $\mathrm{Cu}$ toxicosis in group WFM, but not in groups receiving soya-bean meal or dried skim milk as the protein supplement. Guggenheim (1964) has also presented evidence for a three-way interaction between $\mathrm{Cu}, \mathrm{Zn}$ and $\mathrm{Ca}$. He found that the anaemia in meat-fed mice due to an induced $\mathrm{Cu}$ deficiency was exaggerated by adding $\mathrm{Zn}$ to the diet. The simultaneous addition of $\mathrm{Ca}$ eliminated the effect of $\mathrm{Zn}$.

It is not easy to correlate two further aspects of the response to $\mathrm{Cu}$ supplements in Expt 2, namely, the simultaneous exaggeration of a general condition of $\mathrm{Zn}$ deficiency and the increase in liver $\mathrm{Zn}$ concentrations. The increase of $60 \mu \mathrm{g} \mathrm{Zn} / \mathrm{g}$ liver dry matter is equivalent to an increase of some $18 \mathrm{mg} \mathrm{Zn}$ in the whole liver. The total plasma $\mathrm{Zn}$ pool in a healthy $50 \mathrm{~kg}$ pig would be about $\mathrm{I} \cdot 2 \mathrm{mg}$, assuming a plasma volume of 21. (Hansard, Butler, Comar \& Hobbs, 1953) and a concentration of $60 \mu \mathrm{g}$ $\mathrm{Zn} / \mathrm{roo} \mathrm{ml}$. The increase in liver $\mathrm{Zn}$ content would thus account for the fall of $50 \%$ in plasma $\mathrm{Zn}$ concentration which occurred in our cases of parakeratosis unless this withdrawal of $\mathrm{Zn}$ was corrected by an increased absorption, decreased excretion or mobilization of $\mathrm{Zn}$ from the extensive reserves in the skeleton and soft tissues. The relatively small decreases in tissue $\mathrm{Zn}$ concentrations recorded in $\mathrm{Zn}$-deficient pigs (Hoekstra et al. 1956), rats (Hove, Elvehjem \& Hart, 1938), sheep (Ott, Smith, Stob \& Beeson, 1964) and chickens (Zeigler, Leach, Scott, Huegin, McEvoy \& Strain, 1964) suggest that tissue reserves of $\mathrm{Zn}$ are largely immobile. On the other hand, Kirchgessner \& Weser (1963) found that adding $260 \mathrm{ppm} \mathrm{Cu}$ to the diet of pigs increased the apparent absorption of $\mathrm{Zn}$ by $2 \%$, urinary $\mathrm{Zn}$ excretion being unaffected. The net effect of these various factors on the plasma $\mathrm{Zn}$ pool in the pigs from Expt 2 must remain conjectural, but it is conceivable that the effect of supplementary $\mathrm{Cu}$ in stimulating liver $\mathrm{Zn}$ storage could contribute to the development of $\mathrm{Zn}$ deficiency in other tissues. The nature of the interrelationship between $\mathrm{Cu}$ and $\mathrm{Zn}$ has been discussed more fully in a preceding paper (Suttle \& Mills, I966).

Our investigations sought to explain the conflicting reports about the benefits and dangers of adding $250 \mathrm{ppm} \mathrm{Cu}$ to pig rations as a growth stimulant. They showed that $25^{\circ} \mathrm{ppm} \mathrm{Cu}$ caused mild toxicosis when the basal diet containing $3^{\circ} \mathrm{ppm}$ $\mathrm{Zn}$ was not supplemented with $\mathrm{Zn}$ and $\mathrm{Fe}$ and the $\mathrm{Ca}$ intake was high. The simultaneous administration of $\mathrm{Zn}$ and Fe gave complete protection against the toxic effects of 425 ppm $\mathrm{Cu}$. The separate protective effects of $\mathrm{Zn}$ and Fe were demonstrated previously (Suttle \& Mills, 1966). The routine use of supplements of $\mathrm{Zn}$ and $\mathrm{Fe}$ in Cu-supplemented diets should considerably extend the margin of safety. Several workers have shown that dietary $\mathrm{Cu}$ concentrations ranging from $\mathrm{I} 25$ to $250 \mathrm{ppm}$ are equally effective in stimulating weight increase (Dammers \& Stolk, 1959; Bellis, 196r; Fagan, Iles, Slowitsky \& Brocksopp, I96r; Forshaw, 196r). It is therefore suggested that large-scale comparative trials should be performed to determine the minimum effective level for $\mathrm{Cu}$ supplementation, although in most investigations $25^{\circ} \mathrm{ppm} \mathrm{Cu}$ have caused no apparent ill effects. The use of $\mathrm{Cu}$ supplements in creep feeds or early-weaning diets for pigs should be attended with particular care, in view of the 
requirements of young rapidly growing stock for a generous and balanced mineral intake.

We thank Mr A. W. Boyne for statistical analysis of the results and Mr N. McEchern for his care and maintenance of the animals. We acknowledge the financial support for this work given by the Pig Industry Development Authority.

\section{REFERENCES}

Bellis, D. B. (r96r). Anim. Prod. 3, 89 .

Bellis, D. B. \& Philp, J. McL. (1957). F. Sci. Fd Agric. 8, Suppl. p. 1 9.

Braude, R., Townsend, J. M., Harrington, C. \& Rowell, J. G. (I962). F. agric. Sci., Camb., 58, 251.

Dammers, J. \& Stolk, K. (I959). Versl. landbouwk. Onderz. Ned. 65. 12, I.

Davis, P. N., Norris, J. C. \& Kratzer, F. H. (1962). Y. Nutr. 77, 217.

Dunn, K. M., Ely, R. E. \& Huffman, C. F. (1952). Y. Anim. Sci. 11, 326.

Fagan, V. J., Iles, R. D., Slowitsky, Z. \& Brocksopp, R. E. (1961). f. agric. Sci, Camb., 56, I61.

Forbes, R. M. \& Yohe, M. (1960). F. Nutr. 70, 53.

Forshaw, R. P. (x961). Proc. Can. Soc. Anim. Prod. p. 32.

Gray, L. F. \& Daniel, L. J. (r954). F. Nutr. 53, 43.

Guggenheim, K. (r964). Blood, 23, 786.

Hansard, S. L., Butler, W. O., Comar, C. L. \& Hobbs, C. S. (1953). F. Anim. Sci. 12, 402.

Hansen, M. A. \& Dishington, I. W. (1960). Medlemsblad för den Norske Veterinaerforening, no. I, p. 3.

Hoefer, J. A., Miller, E. R., Ullrey, D. E., Ritchie, H. D. \& Luecke, R. W. (r960). F. Anim. Sci. I9, 249.

Hoekstra, W. G., Lewis, P. K. Jr, Phillips, P. H. \& Grummer, R. H. (1956). Ұ. Anim. Sci. r5, 572.

Hove, E., Elvehjem, C. A. \& Hart, E. B. (1938). Am. Y. Physiol. 124, 750.

Kernkamp, H. C. H. \& Ferrin, E. F. (1953). F. Am. vet. med. Ass. 123, 2 I7.

Kirchgessner, M. \& Weser, U. (1963). Z. Tierernähr. Futtermittelk. r8, r8r.

Leach, R. M., Turk, D. E., Zeigler, T. R. \& Norris, L. C. (1962). Poult. Sci. $41,300$.

Lewis, P. K. Jr, Grummer, R. H. \& Hoekstra, W. G. (1956). F. Anim. Sci. 16, 627.

Lewis, P. K. Jr, Hoekstra, W. G. \& Grummer, R. H. (1957). F. Anim. Sci. 16, 578.

Lucas, I. A. M., Livingstone, R. M. \& McDonald, I. (I96I). Anim. Prod. 3, I I I.

McCall, J. T., Mason, J. V. \& Davis, G. K. (196r). F. Nutr. 74, 5 I.

Månsson, I., Askling, M. \& Manheim, F. (1964). Acta vet. scand. 5, 7.

Oberleas, D., Muhrer, M. E. \& O'Dell, B. L. (1962). F. Anim. Sci. 21, 57.

O'Dell, B. L. \& Savage, J. E. (1960). Proc. Soc. exp. Biol. Med. 103, 304.

O'Hara, P. J., Newman, A. P. \& Jackson, R. (I960). Aust. vet. F. 36, 225.

Ott, E. A. Smith, W. H., Stob, M. \& Beeson, W. M. (1964).. . Nutr. 82, 4I.

Ritchie, H. D., Luecke, R. W., Baltzer, B. V., Miller, E. R., Ullrey, D. E. \& Hoefer, J. A. (r962). Ұ. Anim. Sci. 2r, roro

Ritchie, H. D., Luecke, R. W., Baltzer, B. V., Miller, E. R., Ullrey, D. E. \& Hoefer, J. A. (1963). F. Nutr. 79, 117 .

Smith, W. H., Plumlee, M. P. \& Beeson, W. M. (1962). F. Anim. Sci. 21, 399.

Stevenson, J. W. \& Earle, I. P. (1956). F. Anim. Sci. 15, 1036.

Suttle, N. F. (1964). Dietary factors affecting copper toxicosis in the pig. PhD Thesis, University of Aberdeen.

Suttle, N. F. \& Mills, C. F. (1966). Br. F. Nutr. 20, I35.

Tucker, H. F. \& Salmon, W. D. (1955). Proc. Soc. exp. Biol. Med. 88, 613.

Wallace, H. D., McCall, J. T., Bass, B. \& Combs, G. E. (1960). F. Anim. Sci. r9, I 53.

Zeigler, T. R., Leach, R. M. Jr, Scott, M. L., Huegin, F., McEvoy, R. K. \& Strain, W. H. (1964). F. Nutr. 82, 489 . 